\title{
Researching the glottodidactic potential of selected techniques of working with language material using fMRI
}

\author{
Anna ANTONIUK \\ Uniwersytet Warszawski/ University of Warsaw \\ E-mail: anna.antoniuk@uw.edu.pl, \\ Magdalena OLPIŃSKA-SZKIEŁKO \\ Uniwersytet Warszawski/ University of Warsaw \\ E-mail: m.olpinska@uw.edu.pl,
}

\author{
Agnieszka PLUTA \\ Instytut Fizjologii i Patologii Słuchu/ The Institute of Physiology and Pathology of \\ Hearing, Uniwersytet Warszawski/ University of Warsaw \\ E-mail: a.pluta@ifps.org.pl,

\section{Tomasz WOLAK} \\ Instytut Fizjologii i Patologii Słuchu/ The Institute of Physiology and Pathology of \\ Hearing \\ E-mail: t.wolak@ifps.org.pl,
}

\begin{abstract}
This paper outlines selected results of a glottodidactic study conducted at the Bioimaging Research Center in Kajetany (Poland) using fMRI. The aim of the study was to compare, from the neurolinguistic point of view, selected language activities: retrieving a list of previously memorized words and phrases, retrieving previously memorized short texts, and creating a spontaneous oral statement in a foreign language (L2), in order to assess their potential impact on the development of communicative competence of L2-learners. The study is aimed at answering the following question: the processing of which kind of linguistic information, i.e. in the form of individual phrases or in the form of a text, is more similar to the act of spontaneous speech from the neurobiological perspective. It was assumed that the activity which is more similar to such speech act will probably be more conducive to the development of students' communication skills in the process of learning a foreign language. The results of the study demonstrate that work with a coherent text in foreign language learning and teaching can be more beneficial than working with lists of separate words or phrases.
\end{abstract}

Keywords: (foreign) language learning, communicative competence, discourse, didactic material, neuroimaging, Functional Magnetic Resonance Imaging (fMRI)

\section{Introduction}

This paper is a preliminary attempt to assess the potential impact of selected language activities on the development of L2 learners' communicative skills in the process of 
foreign language learning and teaching by using Functional Magnetic Resonance Imaging (fMRI). The main aim is to compare two selected language activities: 1. retrieving a list of thematically related, previously memorized words and phrases, and 2. retrieving previously memorized short coherent texts on a given subject, with a third language activity, that is, creating a spontaneous oral statement on a given topic in a foreign language (L2). This comparison, made with the help of fMRI, should reveal which task of processing linguistic information, task 1 or task 2, is more similar to the act of spontaneous speech (task 3 ) from a neurobiological point of view. It is assumed that the indicated form of activity will probably be more conducive to the development of communicative competence of learners in the process of learning a foreign language.

The paper is divided into four sections following the Introduction. Section 1 gives a brief overview of the theoretical background of the study. The anthropocentric language theory by F. Grucza is selected and presented as the main reference. In this section we also explain how we define some key concepts for the study, e.g. communicative competence, discourse, and didactic material. The focus of the second section is the fMRI study which was utilized to verify our three research hypotheses, as well as the hypotheses themselves. The section begins with a short literature review on using fMRI to conduct language research. In the third section initial assumptions, research procedure and methodology of the study are examined. The next section presents and discusses selected results of the neurolinguistic experiment that was conducted in February-April 2018 on 8 adults, speaking Russian language as a foreign language (L2), at the Bioimaging Research Center in the Institute of Physiology and Pathology of Hearing in Kajetany near Warsaw ${ }^{1}$. The final section brings our conclusions about the glottodidactic potential of selected techniques of working with language material from the perspective of neurolinguistics.

\section{Theoretical background: the significance of discourse as didactic material in foreign language learning and teaching}

The main objective of this paper is to compare selected mnemonic tasks from the point of view of their effectiveness in the process of learning a foreign language. We want to ascertain how facilitative these techniques of working with language material are in the development of the L2-learners' communicative competence, since the communicative competence is the most important declared aim of learning (and teaching) a foreign language.

The starting point for addressing this issue was the assumption that although the development of the learners' communicative skills has been perceived as the main

\footnotetext{
${ }^{1}$ The fMRI study has been conducted in cooperation with a team of specialists at the Bioimaging Research Center in the Institute of Physiology and Pathology of Hearing in Kajetany on the basis of an agreement on scientific cooperation between the Institute and the University of Warsaw. We sincerely thank Dr Agnieszka Pluta and Dr Tomasz Wolak from the Bioimaging Research Center for their professional assistance and expertise in conducting the study and interpreting its results.
} 
goal of foreign language teaching for at least the last 40 years, an observation can be made that in many cases learning a foreign language does not bring the expected results - in the form of developing these skills among learners - in spite of even strong motivation and considerable amount of work invested in learning. Therefore, it could be deduced that the methods, strategies or/and techniques of foreign language learning and teaching may be not adequate in relation to the intended aim. An answer to the question how to learn a foreign language quickly and effectively, although still very interesting for a great number of people who appreciate the role of foreign language skills both in professional and in private life, has not so far been ascertained and asserted.

The problem of finding the most advantageous methods, techniques, strategies and materials recommended and/or applied in language learning and teaching have been considered by glottodidactics for many years and remains one of the most prominent interests of glottodidactic research. Still, it does not seem easy to answer this question.

Glottodidactics as a scientific discipline strives to find an answer to this question primarily through the systematic exploration and examination of the processes that take place in the minds of the learners during language learning (cf. F. Grucza 2007: 22). On the basis of scientific observation and understanding language acquisition process, glottodidactics tries to evaluate the factors involved in this process and to assess their impact on its final effect (ibid.: 16-17).

As stated above, the most desirable final outcome of L2-learning is now considered to be the development of learners' communicative competence in L2. Learning a foreign language is understood by most glottodidactics practitioners, as it is in this paper, as a process of systematically supporting the development of learners' communicative competence, i.e. the complex skills of understanding and creating language utterances and the ability to use them effectively as means in the communication process (cf. F. Grucza 1993a: 31).

However, as both the literature on the subject (see e.g. M. Olpińska 2013) and an analysis of didactic materials (coursebooks, workbooks, other reference books, etc.) indicate, the majority of the currently used methods of teaching a foreign language, both traditional (cognitive methods, communicative method, direct method and others) and alternative ones (SITA method, Callan method, etc.), focus on the development of lexical competence (development and enrichment of vocabulary) and grammatical competence (knowledge of sentence structures) in learners. It is generally assumed (cf. e.g. H. Komorowska 1999:194) that having "absorbed" the appropriate resource of expressions and language structures (words and phrases) will "automatically" enable learners to use them in the communication process, i.e. to create their own oral and written utterances appropriate to the interlocutor, situation, and to the aim of communication (discourse and pragmatic competence).

Consequently, the focus of research into foreign language teaching is on finding ever more effective ways (methods, techniques and activities) to better acquire and memorize lexical and grammatical material (i.e. multiple repetition of sentence structures, their transformation and creation following an example, learning vocabulary - 
e.g. irregular verbs forms, drills, mini-dialogues, and even so-called role-plays - acting out communication roles using "assigned" phrases). Meanwhile, numerous scientific studies (cf. e.g. C. Srole 1997, W. Butzkamm 2002, S. Even 2003, M. Olpińska 2013, M. Dakowska 2015) clearly indicate that transferring skills from the practice of a given form isolated from the communication context to its application in free communication is simply not successful.

In the face of that evidence, one could assume that to ensure the learner's chance for success the ability to create his or her own utterances must be fostered from the very moment they begin to learn a foreign language. Thus, the activities learners engage in during the learning process should involve the production of full utterances (texts), not individual words or sentences. For the same reason the learning process should be based on the use of the authentic discourse material (texts) (cf. M. Dakowska 2001: 114). In this paper, the notion authentic text is understood as a communicatively appropriate text that is integrated with the communicative situation in which it occurs. Such texts can be considered "sensible units" whose linguistic structure reflects the communication intention, which constitutes the choice and organization of the content of the statement (cf. N. Fries 2005: 143), even when the text is taken out of the original context and analysed in isolation (see S. Grucza 2005: 79, I. Mohr 2005: 18). Didactic materials constructed in this way provide learners with rich language data in the form of language structures occurring in a communicative context and, consequently, fulfil the necessary condition to start the process of language processing. The context plays a crucial role not only in the process of language acquisition but also in the processes of linguistic communication and in the processing of language information by human brains (M. Dakowska 2001: 113, see also M. Szczodrowski 2004: 94, 112 ff.). Thus, language material presented in isolation from the communication context fails in adequately presenting the meaning of language forms and therefore is not conducive to processing and remembering them (cf. W. Butzkamm 2002: 219 ff., W. Grabe/ F.L. Stoller 1997: 7 ff.).

It does not follow, however, that we advocate a complete abandonment of grammar as a factor in ordering the teaching material. Learners should understand language structures both in functional (semantic and situational), as well as in formal (syntactic, structural) terms. But we believe, following W. Butzkamm (2002: 5), that in the process of learning a foreign language the understanding of the meaning of the statement should be the key to "breaking the language code" and not the other way round.

Therefore, the processes of foreign language learning should be initiated in sensible communication situations, because the main objective of foreign language teaching is to enable learners to take part in the language communication process from the very beginning and to gradually build and support the development of their communicative skills. On the way to this goal, formal explanations and appropriate structural exercises are also needed; however, while the explanations and exercises are indispensable, they should not dominate foreign language lessons and the knowledge of the foreign language system should be developed along with the strategic skills of using language expression as means of communication.

Substantiation for these claims can be found in cognitive linguistics, e.g. in the anthropocentric theory of languages by F. Grucza. (1983, 1993a, 1993b, 1996, 1997, 
2005). In the light of this theory, language should be treated as knowledge that underlies human communication skills. This knowledge (linguistic knowledge) is closely related to many other types of knowledge (non-linguistic: general and specialized, and knowledge about the social and cultural conditions of the communication process). It enables humans to participate effectively in language communication. During a communication interaction, people use language expressions arranged in units called discourses, which are the only representations of linguistic knowledge available to other participants in communication processes. Thus, participating in communication acts enables people to create and understand discourse.

In order to describe the processes occurring during the production and perception of language expression, we assume an interactive model of language processing (see e.g. H. Strohner, 2005; W. Schnotz, 2005). Scientific research in the field of psychology, psycholinguistics and neurolinguistics allows an increasingly more precise tracking of the processes involved in creating and understanding linguistic utterances. Scientists have been able to identify three stages in the process of planning and formulating utterances from the moment when the communicative intention appears to its linguistic expression. These include: firstly, the level of conceptualization (W. Levelt 1989, 1992, cf. also A. Caramazza 1997, I. Kurcz 2000, B.M. Schmitt et.al. 2003, G. Rickheit/ L. Sichelschmidt / H. Strohner 2004), where the speaker selects the content he or she is going to express, and the goal he or she wants to achieve using language expressions; secondly, the level of utterance formulation (pre-verbal message generation), at which the selection of proper syntagmatic structures, lexical units and the assignment of the appropriate phonological form to morphemes (grammatical and phonological coding, cf. B.M. Schmitt et.al. 2003: 52, P. Indefrey 2003: 31-32) takes place; and, finally, the level of articulation, at which the verbalization of utterance (the vocal realization of the speech) occurs.

The key assumption in this study is that learning a foreign language, focusing on the two lower stages of language processing (the formulation and articulation of linguistic utterances) and not including the conceptualization stage, does not enable learners to develop the full communicative competence, that is, all linguistic and nonlinguistic skills that they need to operate efficiently and effectively in the communication environment. If we recognize that the most important aim of foreign language teaching is to support the learners' ability to understand and create language utterances and to use them as a means of communication, it seems appropriate to develop and use teaching material as close as possible to authentic discourse and to let the learners perform the linguistic activities (tasks) that are as close as possible to the activities performed in the process of language communication. We can, therefore, assume that appropriately prepared and performed work with a text is more adequate to the assumed L2 teaching aim than working with lists of separate words or phrases.

\section{The study: using fMRI for language research}

Contemporary glottodidactics should be understood as an interdisciplinary scientific field whose research on language processing and learning is based on the cooperation 
with other scientific disciplines such as psychology, psycholinguistics and, in recent years, neurolinguistics.

The introduction of fMRI (Functional Magnetic Resonance Imaging) into language research in the 1990s (review in C.J. Price 2012) enabled the observation of brain activity during language processing. The focus of researchers was primarily on the development of language brain networks (A.D. Friederici 2011, E. Fedorenko et al. 2010, M.A. Skeide/ A.D. Friederici 2016).

When it comes to learning a foreign language (L2), the focus has been on the functional changes in the brain (neural changes) during the process of learning of, for example, new words (J. Yang et al. 2015), also based on artificial languages (B. Opitz/ A.D. Friederici 2003, D. López-Barroso et al. 2015). The brain has been observed during intensive learning and the key role of the left inferior parietal lobule (IPL) in the acquisition of a foreign language has been noticed (E.B. Barbeau et al. 2017). The researchers have been also interested in what the predispositions for learning a foreign language (speaking) are from a neurobiological point of (R.J. Zatorre 2013, Z. Deng/ B. Chandrasekaran/ S. Wang et al. 2015).

The role of context in acquiring new words, as pointed out above, can be confirmed by many fMRI studies. The issues investigated include the differences in the brain activity when learning isolated words and words used in sentences and in texts while reading ( $\mathrm{J}$. Xu et al. 2015, $\mathrm{K}$. Ledoux et al. 2006). The different ways of word acquisition in L2 have also been compared: both through translation into L1 (first language) and through the situational context.

The results of these studies show that learning words through their social context activates language networks in a manner similar to using L1. Pedagogically, this study underlines the importance of learning L2 in a social context because brain activity during the retrieval is similar to that accompanying the retrieval of L1 words (H. Jeong et. al 2010).

The brain activity during speech production has also been the subject of many scientific studies. It is often compared to brain activity accompanying listening (K. Segaert et al. 2011), because both these processes activate the brain areas responsible for syntactic processing (left inferior frontal gyrus, Brodmann's area, left middle temporal gyrus, and bilateral supplementary motor area). However, it has been noticed that the level of language proficiency brings differences in the brain activity while performing tasks consisting in speech production and listening comprehension. Whereas the left dorsal IFG activation related to oral production was negatively correlated with the participants' L2 fluency levels, the left posterior STG region employed for listening comprehension showed a positive correlation with L2 fluency levels. The results of the current studies suggest that more fluent L2 learners require fewer cognitive resources for L2 oral production (K. Shimada et al. 2015).

It is emphasized that the activity of areas related to language production largely overlaps with the areas responsible for non-linguistic cognitive areas (left-lateralized frontotemporal-parietal - FTP system), thus involving it in cognitive control specific to sentential spoken language production.

In recent years, the focus has been on brain activity during a free utterance (and 
not just producing single words), e.g. when describing a picture. It has been emphasized that there is a multitude of factors that accompany this process, such as semantic and syntactic coding and error correction (V. Troiani et al. 2008, M. Grande et al. 2012). Reading aloud has also been compared with spontaneous utterances (V. Ramanarayanan et al. 2010). An attempt has been made to introduce a dialogue into the research on language production, with the focus being not on the speech act itself, but on the conceptualization of utterance, which shows that the social context (interlocutor's presence) is important in this process (A.K. Kuhlen/ C. Bogler 2017).

Few researchers have directly addressed the issues of glottodidactics by using fMRI.

Previous work has largely failed to address the question of adequacy or effectiveness of methods, techniques or materials applied in language teaching.

In the study presented below ${ }^{2}$, the focus is on the glottodidactic potential of selected techniques of work with language materials. During the performance of planned language tasks we expected the areas forming language networks to be active. Drawing on the literature on the subject, we expected that during the memory retrieval of coherent texts and during the creation of a spontaneous statements there would be a greater activation of areas responsible for linguistic processing (mainly on the level of semantization and conceptualization of utterances) than during the memory retrieval of individual language expressions.

The aim of the study was to verify the following research hypotheses.

Research hypothesis No. 1 stated that: the areas of human brain involved in the process of creating language utterances are not always identical to the areas involved in doing language tasks. The study aimed at identifying the language tasks that activate the same or similar brain areas to those activated in the process of language communication. From a variety of possible language activities we have chosen two tasks that are very often performed by L2-learners: 1. reproducing previously memorized lists of thematically related but isolated words and phrases (collocations) and 2. reproducing a previously memorized short, coherent texts on a given subject. All the activities, including the producing of a spontaneous oral statement on a given topic, were performed by the participants in a foreign language, which in this case was Russian.

Research hypothesis No. 2 assumed that: the language tasks that activate the same or similar brain areas to those activated in the process of language communication require from foreign language learners the same or similar activities that they perform while participating in real language communication acts, so they will be more conducive to the development of their communication skills than tasks activating other areas.

Research hypothesis No. 3 assumed that: the brain areas active in the process of memory retrieval of coherent texts will overlap to a larger extent with the areas active in the process of creating spontaneous utterances than the areas active in the process of memory retrieval of individual words and phrases.

In order to examine these hypotheses, brain images were made using Functional Magnetic Resonance Imaging (fMRI). In order to eliminate as many variables that could affect the interpretation of imaging results as possible, the fMRI study was conducted on a homogeneous group of 8 volunteers: right-handed women aged 20-25,

\footnotetext{
${ }^{2}$ The study presented in this paper is a pilot study for a planned research project on this subject.
} 
not suffering from claustrophobia, who speak Russian as a foreign language (L2) at B1 + / B2 level. The study participants were examined while performing all three types of tasks mentioned above. Each of the three tasks consisted of four exercises devoted to different subject areas; the exercises were selected in a randomized manner for each participant (a total of four lists of words, four texts and four spontaneous statements in a random order). The thematic scope in each task for one participant was identical to eliminate or limit to the minimum the impact of non-linguistic factors (such as different levels of general and specialist knowledge). During the study, brain areas activated in the participants during the performing of tasks were observed and compared with each other.

The study was approved by the Ethics Committee of the University of Warsaw (Poland). Written informed consent was obtained from each participant.

\section{Research methodology}

The structural magnetic resonance images (MRIs) of the subjects were acquired using a 3T Siemens TIM TRIO VB17 whole-body magnetic resonance scanner with a 12channel head matrix coil.

The fMRI data analyses were done in MATLAB and the Statistical Parametrical Mapping software (SPM 12, Wellcome Department of Cognitive Neurology, London, UK) using a standard pre-processing pipeline: slice-timing; re-alignment ( 3 translations and 3 rotations), co-registration of EPI images and the T1 MPR image; tissue segmentation of the T1 image; normalisation of the T1 MPR image to the MNI template; smoothing with a $6 \mathrm{~mm}$ FWHM kernel, high-pass filtering of $128 \mathrm{~s}$. It was followed by first- and second-level analysis.

Functional Protocol: block design paradigm included 4 types of blocks consisting of word lists, texts, spontaneous speech and rest periods. Each block took 20 seconds. Language tasks, i.e. word lists, texts, and spontaneous speech, were separated by rest blocks in a random sequence; each task appeared 4 times.

The functional paradigm was repeated twice. During the first sequence the subjects were asked to perform the tasks in silence and during the second sequence they spoke aloud. To minimize any residual stimulus-correlated motion artifacts, the subjects were trained to speak softly and to minimize movements of head and facial muscles.

\section{The results}

As shown in Figure 1, all the three tasks (word lists reproduction versus baseline, texts reproduction versus baseline, spontaneous speech) activate the distributed language network comprising Inferior Frontal Gyrus (IFG), anterior and superior temporal gyrus (STG). Inferior Frontal Gyrus (IFG) plays a crucial role in producing language: it processes lexical information and phonological inputs. STG is involved in lexicalsemantic categorization. The joint activation of IFG and STG enables the production of meaningful sentences. In line with other studies (cf. E. Fedorenco 2014), speech production (in all the three tasks) activates additional brain areas (putamen, Middle 
Frontal Gyrus, parietal lobule, parts of the insular cortex, pre-supplementary and supplementary motor area, occipital cortices), which support cognitive control, planning, attention, retrieval and visual imagery.

The direct comparison of the brain activity during text reproduction and word lists retrieval revealed increased neural activation in the middle and superior temporal gyrus as well as the supramarginal gyrus in the left hemisphere. These regions subserve language and semantic memory processing, phonological word form detection, semantic and syntactic processing as well as multimodal sensory integration (S.M. Wilson/ A. Bautista/ A. McCarron 2018).

Similar activation of subregions of superior temporal sulcus (STS), i.e. the area separating the superior temporal gyrus from the middle temporal gyrus in the temporal lobe of the brain, was observed during spontaneous speech generation (but not during word lists reproduction). Spontaneous speech generation showed increased activation of the language network, as well as frontal, temporal and parietal networks involved in executive functions, lexical-semantic categorization and attention, in comparison with other tasks.

The results suggest that both texts reproduction and spontaneous speech involve semantic and syntactic processing. In line with our hypothesis, spontaneous speech generation proves to be cognitively the most demanding task.

\begin{tabular}{|c|c|c|}
\hline Words vs baseline & Text vs baseline & $\begin{array}{c}\text { Spontaneous speech vs } \\
\text { baseline }\end{array}$ \\
\hline & & \\
\hline & & \\
\hline
\end{tabular}

\begin{tabular}{|l|l|l|}
\hline Text vs words & Spontaneous speech vs words & Spontaneous speech vs text \\
\hline & & \\
\hline & & \\
\hline
\end{tabular}

Figure 1. The brain activity during the pilot study.

\section{Conclusions}

The evidence from the study of brain activity while performing three selected language tasks suggests that the assumptions about the foreign language learning expressed in research hypotheses could be confirmed. 
The neural activation of participants while creating a spontaneous oral statement on a given topic in L2 was the largest in comparison with the other two language tasks (research hypothesis No. 1). The act of spontaneous speech proved to be cognitively the most demanding task.

The observation of neural activity during the retrieving of previously memorized texts and producing a spontaneous utterance in L2 revealed increased activation of middle and superior temporal gyrus (STG), as well as of subregions of superior temporal sulcus (STS) in comparison with the activity during reproduction of previously memorized words and collocations (research hypothesis No 3). the findings of the study indicate that the brain activity while the participants retrieve coherent texts, although not identical, is more similar to the activity accompanying speech production, i.e. language communication, than to the one that we observe during the retrieval of isolated words and phrases devoid of context. Consequently, it can concluded that working with language material (didactic material) in the form of coherent discourse may be more productive in foreign language learning and teaching, and, as a result, more beneficial for the development of the learner's communicative skills (research hypothesis No 2).

Although the technique of memorizing the language material, both word lists and texts, by the participants of the experiment (applied techniques, working memory, etc.), were not the subject of research, the influence of information processing depth on memorization cannot be completely ruled out or ignored. As M. Dakowska (2001: $114 \mathrm{ff}$.) points out, language material constituting the logical whole and carrying important content for the receiver is more quickly and easily remembered. This could be considered a further argument in favour of the claim that a language should be learnt in context and with the application of discourse. Learning individual words or phrases does not seem to meet these criteria.

Empirical confirmation of our research hypotheses allows us to formulate important conclusions that may be useful by creating new or verifying traditional didactic materials, as well as by choosing and didactically justifying the methods, strategies and techniques in foreign language learning and teaching. We hope that the results of our study will constitute a significant contribution to the development of contemporary glottodidactics as an independent scientific discipline and initiate further research in this field.

\section{References}

Barbeau, E.B./ X.J Chai/ J.K. Chen/ J. Soles/ J. Berken/ S. Baum/ K.E. Watkins/ D. Klein (2017), The role of the left inferior parietal lobule in second language learning: An intensive language training fMRI study. In: "Neuropsychologia" 98, 169-176.

Butzkamm, W. (2002), Psycholinguistik des Fremdsprachenunterrichts. Tübingen/ Basel.

Caramazza, A. (1997), How many levels of processing are there in lexical access?. In: "Cognitive Neuropsychology" 14 (1), 177-208. 
Dakowska, M. (2001), Psycholingwistyczne podstawy dydaktyki języków obcych. Warszawa.

Dakowska, M. (2015), In Search of Processes of Language Use in Foreign Language Didactics. Franfkfurt.

Deng, Z./ B. Chandrasekaran/ S. Wang/ P.C.M. Wong (2015), Resting-state low-frequency fluctuations reflect individual differences in spoken language learning. In: "Cortex" 76, 63-76.

Even, S. (2003), Drama Grammatik. Dramapädagogische Ansätze für den Grammatikunterricht Deutsch als Fremdsprache. München.

Fedorenko, E./ P.J. Hsieh/ A. Nieto-Castañón/ S. Whitfield-Gabrieli/ N. Kanwisher (2010), New Method for fMRI Investigations of Language: Defining ROIs Functionally in Individual Subjects. (in:) "Journal of Neurophysiology" 104, 1177-1194.

Fedorenko, E. (2014), The role of domain-general cognitive control in language comprehension. In: "Frontiers in Psychology" 5 (335), https://doi.org/10.3389/fpsyg.2014.00335.

Friederici, A.D. (2011), The brain basis of language processing: from structure to function. In: "Physiological Rewievs" 91 (4), 1357-1392.

Fries, N. (2005), Textkompetenz: ein Essay über ausgewählte sprachspezifische und interkulturelle Aspekte. In: F. Grucza (ed.), Germanistische Erfahrungen und Perspektiven der Interkulturalität. Warszawa, 150-161.

Grabe, W./ F.L. Stoller (1997), Content-Based Instruction: Research Foundations. In: M.A. Snow/ D.M. Brinton (eds.), The Content-Based Classroom. Perspectives on Integrating Language and Content. New York, 5-21.

Grande, M./ E. Meffert/ E. Schoenberger/ S. Jung/ T. Frauenrath/ W. Huber/ K. Hussmann/ S. Heim (2012), From a concept to a word in a syntactically complete sentence: An fMRI study on spontaneous language production in an overt picture description task. In: "Neuroimage" 61, 702-714.

Grucza, F. (1983), Zagadnienia Metalingwistyki. Lingwistyka - jej przedmiot, lingwistyka stosowana. Warszawa [zob. http://www.iksi.uw.edu.pl/documents/11738337/14640936/FG_Tom_8.pdf].

Grucza, F. (1993a), Zagadnienia ontologii lingwistycznej: o językach ludzkich i ich (rzeczywistym) istnieniu. In: "Opuscula logopedica in honorem Leonis Kaczmarek". Lublin, 25-47 [zob. http://www.iksi.uw.edu.pl/documents/11738337/14640936/FG_Tom_3.pdf, 71-96].

Grucza, F. (1993b), Język, ludzkie właściwości językowe, językowa zdolność ludzi. In: J. Piontek/ A. Wiercińska (eds.), Człowiek w perspektywie ujęć biokulturowych. Poznań, 151-174 [zob. http://www.iksi.uw.edu.pl/documents/11738337/14640936/FG_Tom_3.pdf, 43-69].

Grucza, F. (1996), O przeciwstawności ludzkich interesów i dązeń komunikacyjnych, interkulturowym porozumiewaniu się oraz naukach humanistyczno-społecznych. In: F. Grucza/ K. Chomicz-Jung (eds.), Problemy komunikacji interkulturowej: Jedna Europa - wiele języków i wiele kultur. Warszawa, 11-31.

Grucza, F. (1997), Języki ludzkie a wyrażenia językowe, wiedza a informacja, mózg a umyst ludzki. In: F. Grucza/ M. Dakowska (eds.), Podejścia kognitywne w lingwistyce, translatoryce i glottodydaktyce. Warszawa, 7-21. 
Grucza, F. (2005), Wyrażenie „upowszechnianie nauki”-jego status i znaczenie w świetle teorii aktów komunikacyjnych i lingwistyki tekstów. In: F. Grucza/ W. Wiśniewski (eds.), Teoria i praktyka upowszechniania nauki wczoraj i jutro. Warszawa, 41-76 [zob. http://www.iksi.uw.edu.pl/documents/11738337/14640936/FG_Tom_2.pdf, 105-135].

Grucza, F. (2007), Lingwistyka stosowana. Historia - Zadania - Osiagnięcia. Warszawa [zob. http://www.iksi.uw.edu.pl/documents/11738337/14640936/FG_Tom_9.pdf].

Grucza, S. (2005), Autentyczność i oryginalność tekstów a glottodydaktyczne nieporozumienia w tej sprawie. In: "Przegląd Glottodydaktyczny" 19, 75-83.

Indefrey, P. (2003), Hirnaktivierungen bei syntaktischer Sprachverarbeitung: eine Meta-Analyse. In: H.M. Müller/ G. Rickheit (eds.), Neurokognition der Sprache. Tübingen, 31-50.

Jeong, H./ M. Sugiura/ Y. Sassa/ K. Wakusawa/ K. Horie/ S. Sato./ R. Kawashima (2010), Learning second language vocabulary: Neural dissociation of situationbased learning and text-based learning. In: "Neuroimage" 50, 802-809.

Komorowska, H. (1999), Metodyka nauczania języków obcych. Warszawa.

Kuhlen, A.K./ C. Bogler (2017), Brains in dialogue: Decoding neural preparation of speaking to a conversational partner. In: "Social Cognitive and Affective Neuroscience" 2017, 1-10.

Kurcz, I. (2000), Psychologia języka i komunikacji. Warszawa.

Ledoux, K./ J. Hopkins/ C.C. Camblin/ T.Y. Swaab/ D.P.C. Gordon (2006), Reading Words in Discourse: The Modulation of Lexical Priming Effects by MessageLevel Context. In: "Behavioral and Cognitive Neuroscience Reviews" 5 (3), 107127.

Levelt, W.J.M. (1989), Speaking: From intention to articulation. Cambridge.

Levelt, W.J.M. (1992), Accessing words in speech production. Stages, processes and representations. In: “Cognition” 42, 1-22.

López-Barroso, D./ P. Ripollés/ J. Marco-Pallarés/ B. Mohammadi/ T.F. Münte/ A.-C. Bachoud-Lévi/ A. Rodriguez-Fornells./ R. Diego-Balaguer (2015), Multiple brain networks underpinning word learning from fluent speech revealed by independent component analysis. In: "Neuroimage" 110, 182-193.

Mohr, I. (2005), Deutsch ist zwischen uns einfach ein Thema gewesen. Immer! ". Untersuchung zu Sprach- und Textkompetenz in der Zweitsprache von SchülerInnen mit Migrationshintergrund in der Oberschule. Wien.

Olpińska, M. (2013), Nauczanie dwujęzyczne w świetle badań glottodydaktycznych. Warszawa.

Opitz, B./ A.D. Friederici (2003), Interactions of the hippocampal system and the prefrontal cortex in learning language-like rules. In: "NeuroImage" 19 (4), 17301737.

Price, C.J. (2012), A review and synthesis of the first 20 years of PET and fMRI studies of heard speech,spoken language and reading. In: "Neuroimage" 62, 816-847. 
Ramanarayanan, V./ D. Byrd/ L. Goldstein/ S. Narayanan (2010), Investigating articulatory setting - Pauses, ready position, and rest - Using real-time MRI. Conference of the International Speech Communication Association, Makuhari, Chiba, Japan, September 26-30 2010.

Rickheit, G./ L. Sichelschmidt/ H. Strohner (2004), Psycholinguistik. Tübingen.

Schmitt, B.M./ N.O. Schiller/ A. Rodriguez-Fornells/ T.F. Münte (2003), Elektrophysiologische Studien zum Zeitverlauf von Sprachprozessen. In: H.M. Müller/ G. Rickheit (eds.), Neurokognition der Sprache. Tübingen, 51-70.

Schnotz, W. (2005), Was geschieht im Kopf des Lesers? Mentale Konstruktionsprozesse beim Textverstehen aus der Sicht der Linguistik und der Psychologie. In: H. Blühdorn/ E. Breindl/ U.H. Wassner (eds.), Text - Verstehen. Grammatik und darüber hinaus. Berlin, New York, 222-238.

Segaert, K./ L. Menenti/ K. Weber/ P. Hagoort (2011), Shared Syntax in Language Production and Language Comprehension - An fMRI Study. In: "Cerebral Cortex" 22(7), 1662-1670.

Shimada, K./ M. Hirotani/ H. Yokokawa/ H. Yoshida/ K. Makita/ M. Yamazaki-Murase/ H.C. Tanabe/ N. Sadato (2015), Fluency-dependent cortical activation associated with speech production and comprehension in second language learners. In: "Neuroscience" 300, 474-92.

Skeide, M.A./ A.D. Friederici (2016), The ontogeny of the cortical language network. In: "Neuroscience" 7, 323-332.

Srole, C. (1997), Pedagogical Responses from Content Faculty: Teaching Content and Language in History. In: M.A. Snow/ D.M. Brinton (eds.), The ContentBased Classroom. Perspectives on Integrating Language and Content. New York, 104-116.

Strohner, H. (2005), Textverstehen aus psycholinguistischer Sicht. In: H. Blühdorn/ E. Breindl/ U.H. Wassner (eds.), Text - Verstehen. Grammatik und darüber hinaus. Berlin, New York, 187-204.

Szczodrowski, M. (2004), Glottokodematyka a nauka języków obcych. Gdańsk.

Troiani, V./ M.A. Fernández-Seara/ Z. Wang/ J.A. Detre/ S. Ash/ M. Grossman (2008), Narrative speech production: an fMRI study using continuous arterial spin labeling. In: "Neuroimage" 40, 932-939.

Wilson, S.M./ A. Bautista/ A. Mc Carron (2018), Convergence of spoken and written language processing in the superior temporal sulcus. In: "Neuroimage" 171, 62-74.

Xu, J./ S. Kemeny/ G. Park/ C. Frattali/ A. Brau (2005), Language in context: emergent features of word, sentence, and narrative comprehension. In: "Neuroimage" $25,1002-1015$.

Yang, J./ K.M. Gates/ P. Molenaar/P. Li (2015), Neural changes underlying successful second language word learning: An fMRI study. In: "Journal of Neurolinguistics" 33, 29-49.

Zatorre, R. J. (2013), Predispositions and plasticity in music and speech learning: neural correlates and implications. In: "Science" 342(6158), 585-589. 